Portland State University

PDXScholar

\title{
An Analysis of the Six Military-Dominated Political Cycles in El Salvador Between 1931 and 1979
}

Thomas Ramon Rookard

Portland State University

Follow this and additional works at: https://pdxscholar.library.pdx.edu/open_access_etds

Part of the Latin American History Commons, and the Political History Commons Let us know how access to this document benefits you.

\section{Recommended Citation}

Rookard, Thomas Ramon, "An Analysis of the Six Military-Dominated Political Cycles in El Salvador Between 1931 and 1979" (1985). Dissertations and Theses. Paper 3520.

https://doi.org/10.15760/etd.5404

This Thesis is brought to you for free and open access. It has been accepted for inclusion in Dissertations and Theses by an authorized administrator of PDXScholar. Please contact us if we can make this document more accessible: pdxscholar@pdx.edu. 
AN ABSTRACT OF THE THESIS OF Thomas Ramon Rookard for the Master of Arts in History presented March 12, 1985.

Title: An Analysis of the Six Military-Dominated Political Cycles in El Salvador Between 1931 and 1979 .

\section{APPROVED BY MEMBERS OF THE THESIS COMMITTEE:}
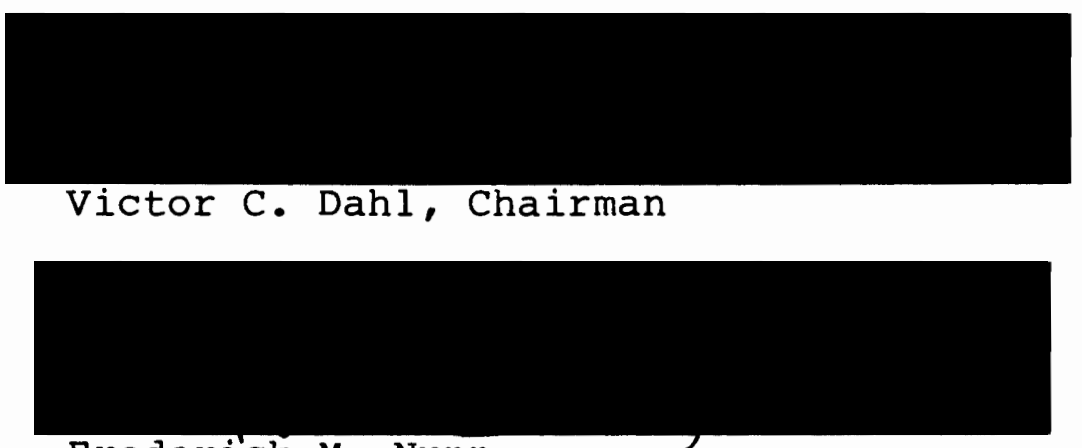

Frederick M. Nunn

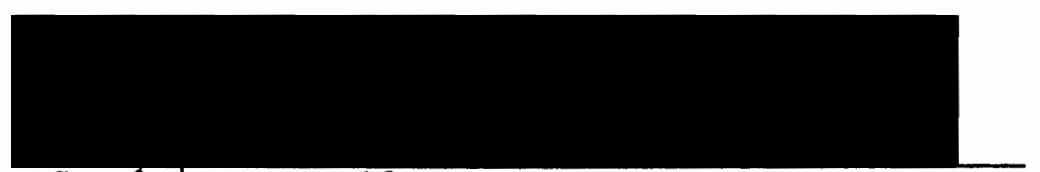

Gordoy B. Dodds

A comparative study of the cycles of military-political power in El Salvador between 1931 and 1979 indicates that the country was convulsed six times by political struggle. A pattern emerged wherein the military asserted itself as maintainer of the status quo each time that repression of, or concession to, the masses threatened the economic and political balance. 
Just as a cyclical pattern of economic development had evolved in the colonial period, so a similar pattern emerged in El Salvador's political life after 1932. In the first case, economic power was consolidated in a few hands, i.e., those of the oligarchy; in the second instance, political power was perpetuated in the hands of the army. Meanwhile, the economic situation continued unchanged, and those reforms that occurred in no way affected the sources and distribution of wealth or control of the national economy. Throughout the decades following the assumption of power by the military in symbiotic alliance with the oligarchy, two goals remained paramount. One was the protection of the interests of the oligarchy. The second was the preservation of the army as an institution.

The main purpose of this paper is to examine the critical characteristics of these political cycles which led to my conclusion that they threaten to perpetuate the massive poverty and social inequality prevalent in $\mathrm{El}$ Salvador unless radical measures are taken to alter the political, social and economic conditions in that country. 
AN ANALYSIS OF THE SIX MILITARY-DOMINATED POLITICAL CYCLES IN EL SALVADOR BETWEEN 1931 AND 1979

by

THOMAS RAMON ROOKARD

A thesis submitted in partial fulfillment of the requirements for the degree of

\author{
MASTER OF ARTS \\ in \\ HISTORY
}

Portland State University 
TO THE OFFICE OF GRADUATE STUDIES AND RESEARCH:

The members of the Committee approve the thesis of Thomas Ramon Rookard presented March 12, 1985.

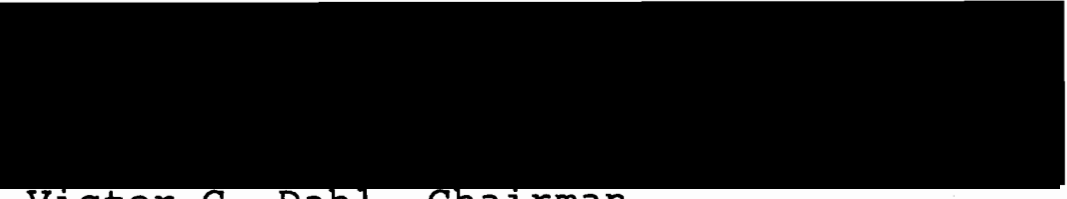

Victor C. Dahl, Chairman

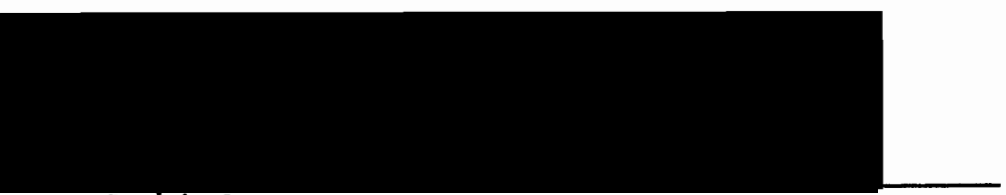

Frederick M. Nunn

Gordor G. Dodds

APPROVED :

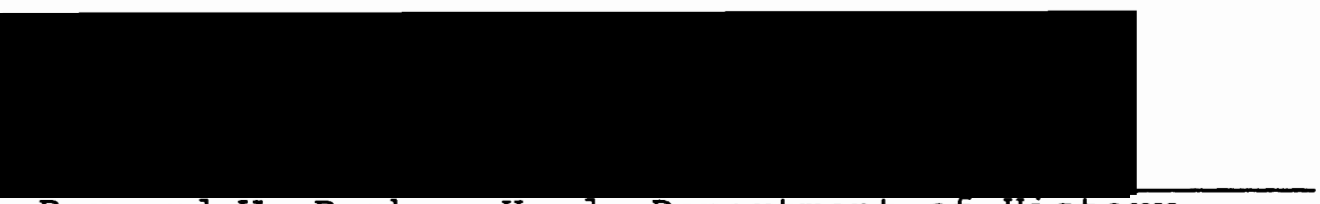

Bernard V. Burke, Head, Department of History

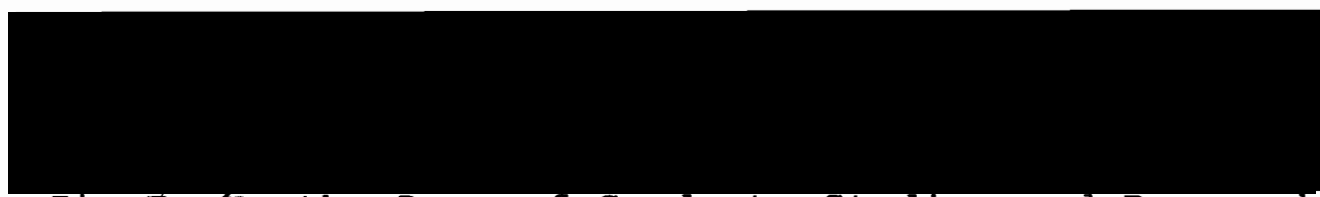

Jim E. Heath, Dean of Graduate Studies and Research 


\section{ACKNOWLEDGMENTS}

To the people in the town of Santa Tecla (Nuevo San Salvador), El Salvador, Doña Dolores L. and her son Edgar who made me a part of their family during my stay in El Salvador, and to the various individuals who were employed at the National Library and other government facilities in El Salvador, grateful acknowledgment is made. Without their tolerance of a gringo whose use of the Spanish language left much to be desired, much of the material included in this work would be superficial at best.

To the Peace Corps volunteers and trainees, staff members of the Center for Human Potential, Kate Rafftery in particular, and to everyone who contributed to my education in Costa Rica and the Dominican Republic, as well as El Salvador, deep thanks is rendered.

To the Latin Americanists on the faculty of Portland State University, particularly Drs. Dale Courtney, Victor Dahl, and Frederick Nunn, who stimulated my interest in Latin America and its unique history, I am particularly grateful. 
TABLE OF CONTENTS

PAGE

ACKNOWLEDGMENTS

CHAPTER

I HISTORICAL OVERVIEW: CULTURE, ECONOMY, POLITICS AND SOCIETY . . . . . . . . 1

II BIRTH OF THE MILITARY INSTITUTION $\ldots$. . 17

III THE FIRST THREE CYCLES: THE LONGEST AND THE SHORTEST ........... . 28

IV THE FINAL THREE CYCLES: DETERIORATION OF THE STATUS QUO . . . . . . . . .

$\mathrm{V}$ CONCLUSIONS .............

GLOSSARY

A SELECTED BIBLIOGRAPHY . . . . . . . . . . . 


\section{CHAPTER I}

HISTORICAL OVERVIEW: CULTURE, ECONOMY, POLITICS AND SOCIETY

El Salvador has never been prominently featured by international business magazines, tourist advertisements, or textbooks as an exotic garden spot of Central America peopled by curious backward remnants of the Mayan Indian empire with its citizens spending their time engaged in such handicraft arts as weaving and living in isolation from the rest of society. Rather, its only exceptional national characteristic, other than the fact that its people are notably hardworking, is the fact that its Indian population has been virtually assimilated and there are no significant ethnic or racial minorities. The 1980 population consists of approximately 4,700,000 people of which 92.3 percent are mestizo, 5.6 percent are Indian, and 2.1 percent are white.

The smallest mainland country of Latin America, El Salvador is 8,259 square miles $(21,000 \mathrm{sq} . \mathrm{km}$.$) in area,$ about the same size as the state of Massachusetts. It is also the most heavily populated, having in 1971 a density of 460 persons per square mile with projections for 1980 of 580

1

Tommie Sue Montgomery, Revolution in El Salvador (Boulder: Westview Press, 1982), p. 38. These statistics are probably accurate though somewhat outdated. 
2

persons per square mile. Within all of Middle America, only some Caribbean islands have similar overall population densities.

El Salvador, mountainous and volcanic, is the only Central American country without a Caribbean coast; it therefore lacks a port facing eastward toward its United States and European markets. The country is bounded by Guatemala on the west, Honduras on the north and east, and the Pacific Ocean on the south. Part of the eastern territory lies along the Gulf of Fonseca which El Salvador shares with Honduras and Nicaragua. Several small islands in the gulf are under Salvadorean sovereignty.

Pre-Spanish peoples migrating south and east from Mexico and Guatemala chose to cross through what is now Salvadorean territory, finding its terrain more favorable for travel than that of Honduras. This geographical position as a crossroads country has had political consequences for El Salvador. For example, when she broke away from the United Provinces of Central America in 1838 , the rest of the provinces to the southeast were effectively cut off from the capital in Guatemala City, thus expediting

2

Robert C. West and John F. Augelli, Middle America: Its Lands and Peoples (Englewood Cliffs: Prentice-Hall, Inc., 1976), p. 420 . 
their independence.

El Salvador has an agreeable climate, with most of the population living at an altitude above 2,500 feet 1762 meters). Only on the southeastern coastal lowlands do temperatures regularly become uncomfortably hot. With most of its surface below 3,000 feet (915 meters) elevation, El Salvador lies almost entirely in tierra caliente. The higher slopes of the large volcanoes reach into the tierra templada, where coffee is the main crop. Like most of the Pacific side of Central America, El Salvador experiences a long dry season (December-April) to which most agricultural activity is closely adjusted.

The dense population and lack of unsettled land for expansion has led to the destroying of large numbers of animals native to the area, such as deer, armadillo, puma, jaguar, ocelot, peccary, coyote, and tapir. It has a large bird population, with several varieties known in the United States, as well as various types of parrots and the quetzal. Among the large reptiles are the caiman, a relative of the crocodile, the iguana, and the strong-coiled boa constrictor.

The mountain slopes are forested with many species of 3

Howard I. Blutstein and others, Area Handbook for El Salvador (Washington, D.C.: U.S. Gov't Printing Office, 1971): p. 7 .

4

West, Middle America, p. 420. 
trees valued in cabinetmaking and construction including mahogany, cedar, and walnut. Unfortunately, most forests have been cut and used for firewood and charcoal, thus depleting a valuable resource. A familiar tree in the countryside is the ceiba, or silk-cotton tree, from which kapok is obtained. The most famous tree, however, is the balsam of Peru, which produces a thick, dark, sticky gum used in perfume manufacturing and as a base for some medicines. This misnamed tree is found only in a limited area of El Salvador and supplies the entire world with its gum.

Apart from its dwindling forest resources and abundant water, El Salvador possesses limited mineral reserves. Gold, silver, mercury and lead are mined and exported in small quantities. Other minerals include copper, gypsum, sulphur, alum and zinc.

The economy varies little from that of its Central American neighbors. Agriculture and stock-raising are basic, employing sixty-three percent of the Salvadorean people. Coffee and cotton are the main export crops, but sugar, maize, beans and rice are also grown. Since the nineteenth century El Salvador has had to import basic foods

\section{5}

Alastair White, El Salvador (New York: Praeger Publishers, 1973), p. 32. 6 West, Middle America, p. 421. 
such as maize, beans, and wheat from Honduras, Nicaragua, Guatemala, and overseas producers in order to feed itself.

Small pyramids dating from the start of the Maya civilization, five to fifteen centuries before the arrival of the Spaniards, appear in the western region. The smallness of these monuments indicates that $\mathrm{El}$ Salvador lay on the outskirts of Mayan civilization. Before the entry of the conquistadores, Náhuatl-speaking Aztec people, the Pipil, from the Mexican highlands beyond Guatemala, almost entirely replaced the Mayans. The Spaniards first encountered these people in 1522 .

That first group had sailed from the Pacific coast of Panama with the intention of going to the Spice Islands. Damage to their ships prompted them to give up their original destination, exploring instead the southern coast of Central America in search of gold. They journeyed as far as the Gulf of Fonseca. This expedition made no effort to conquer the gulf Indians. They had learned a lesson in an earlier attempt to subdue a tribe further east.

The next Spaniards to arrive came overland in 1524 from the direction of Mexico and Guatemala intending to add the region to their conquests. The Pipiles resisted, however, and forced Pedro de Alvarado, Hernán Cortés's captain, to

7 8

White, El Salvador, p. 23

Ibid., p. 23. 
abandon plans for a conquest at that time. A year later Alvarado sent his brother Gonzalo back to establish a settlement, Villa San Salvador, which the stubborn Pipiles later burned to the ground. A third expedition in 1528 reestablished the settlement; and constant Spanish harassment prompted the Pipil Indians to revolt, producing the first wave of colonist repression of the indigenous population. Rebellions continued for a decade, but by 1539 the Spaniards had established their dominance in the territory.

The Pipal social and political system that the Spanish disrupted and ultimately destroyed was a "military democracy organized by tribe, with common ownership of the land." The class system society practiced monogamy and slavery. Pipil society enslaved people captured in war or perpetrating civil wrong; native slavery was not hereditary but differed from that practiced by the spaniards.

Captured and enslaved Indians generally served as carriers on Spanish expeditions and would be sold when the expedition returned. The crown, when advised of this practice, decreed that only rebel Indians could be enslaved. It feared that the Indians would be annihilated in a manner

9

Santiago Barbarena, Historia de El Salvador [History of El Salvador] (San Salvador: n.p., 1914-1917), quoted in Montgomery, Revolution in El Salvador, p. 33. 
similar to that which had occurred in Hispaniola and Cuba. These orders from the crown encouraged some commanders to provoke their slaves to rebellion by extreme cruelty in order to have legal grounds for taking and retaking slaves. Fortunately for the Indians of El Salvador, very few conquistadores maintained any interest in an agricultural occupation; likewise, the relative scarcity of valuable minerals such as gold and silver attracted few Europeans to El Salvador in this early period. Those who did arrive and stay lived in relative poverty, relative to their expectations, that is; and although some gold and silver were found, export crops were the base of El Salvador's early economy. The colonists introduced cattle and sheep at this time and began the cultivation of cereals for local consumption.

After it became clear that the wealth of El Salvador lay in the land, the first search for "the key to wealth" 11 began. This search was the first step in a series of

10

White, El Salvador, p. 29, and Montgomery, Revolution in El Salvador, p. 35. Climatic changes caused by shifting Indians to the coast from the highlands to work created health problems as did imported disease. Many Indians died as a result of these factors. 11

Murdo J. MacLeod, Spanish Central America: A Socioeconomic History 1520-1720 (Berkeley: University of California Press, 1973), p. 49. Montgomery, Revolution in El Salvador, p. 199, fn. 11, credits Macleod with the concept of a repeating economic cycle, as do I. 
three major economic cycles that would commence with the discovery of a suitable export crop: development of that crop, a period of prosperity from the export of the crop, relative decline or stagnation for a time, economic depression during which a search for a replacement crop ensued, discovery of that replacement, and initiation of a new economic cycle. The first cycle was a product already grown and in use by the Indians when the Spanish arrived: cocoa.

Cocoa was being grown and processed as a beverage by the Indians; but the conquerors soon took control, and the Indians were forced to deal with the Spanish and then mestizo exporters. The encomienda, ${ }^{12}$ or royal grant system, rapidly evolved, and exporting was dominated by encomenderos by the early 1540s. With the growing popularity of cocoa in Europe, prices rose and so did the fortunes of the encomenderos and criollo and mestizo merchants.

The economic cycle featuring cocoa peaked in the 1570s, but the Indian population decline, coupled with a halt in the importation of slaves, soon began to take its toll on

\section{2}

Charles Gibson, Spain in America (New York: Harper \& Row, 1966), p. 48. Gibson provides insight on Spanish colonial institutions. For example, he explains that definitions such as encomienda were provided after the event, with the development occurring before any need to define it was recognized. 
the cocoa plantations. Smaller encomiendas began reverting to the crown, while the larger ones consolidated their power. By 1600 the boom ended and the economic decline had begun. Depression was in full force by 1610 and continued for half a century, producing the first extended economic crisis in El Salvador. This depression profoundly affected the future of the county by spawning two institutions that would shape the economic, political, and social life of the country. These institutions were the hacienda system and debt peonage.

The decline of cocoa set off a search for a replacement crop, but first the criollo population had to take steps to insure their very survival while centering on that export crop. The result was the establishment of self-sufficient haciendas in the countryside, a new emphasis on cattle breeding and the cultivation of maize, with a subsequent rural rather than urban population growth.

The search for the second key to wealth in El Salvador led to indigo. The geographical conditions of El Salvador were particularly suited to the cultivation of indigo. The obstacle which had impeded its expansion as an export crop prior to the early eighteenth century was the protection given the producers of less efficient blue dye processes using old world plants such as woad, a plant with leaves that yield a blue dye. In Nuremberg in the 1570s, for 
example, "the dyers met once a year and swore not to use indigo, and anyone who broke the oath was liable to the sentence of death." 13 The pressure of finding a more economical and desirable coloring agent gradually influenced European processors to consider abandoning the old ways, and in 1737 laws were passed to allow the use of indigo in the blue dye industry.

By the second half of the eighteenth century, demand in Europe had stimulated the intensive cultivation of indigo. The product then dominated the economy of El Salvador, and the country's second economic cycle was underway. Unlike cocoa, which was a labor-intensive crop, indigo required little attention during its growing period. However, it did require increased numbers of workers during the collection period; this led to the hacienda system.

The first Spanish settlers had brought cattle and chickens which became an important part of the hacienda economy. Because these animals did not eat the indigo plant, fenced areas were unnecessary. The cattle provided meat and milk and served as draft animals. The Indians, who

\section{3} 14

White, El Salvador, p. 45.

Gibson, Spain in America, p. 118. Gibson observes that haciendas in Central America were common to abundant labor sources (Indians). He also states that while historians once felt that hacienda developed from the declining encomienda, the two histories are now regarded as distinct. 
had lost their communal lands through various and devious methods, provided the labor. The frequent confiscation of Indian land was accompanied by efforts to persuade Indians to leave their villages and attach themselves to an hacienda as colonos or aparceros. Colonos, virtual serfs, received small plots (milpas) to grow food, and in return they paid the patrón rent or provided labor for a specified time. Aparceros were essentially sharecroppers.

Encomendero exploitation gave way to repartimiento and debt peonage. Repartimiento consisted of a rotation system of draft labor imposed on indigenous villages, with all men of the village supposedly providing an equal share of labor. Debt peonage bound peons to an hacienda by granting them credit or food and other supplies with the result that they usually were so far in debt that they could never recover. These people were virtually dependent upon their patrón for their very existence.

The result of the economic and social pressures exerted during the indigo cycle was the establishment of patterns of land tenure in El Salvador that would endure into the last quarter of the twentieth century. During this cycle new

15

Montgomery, Revolution in El Salvador, p. 37. The author cites MacLeod, Spanish Central America, pp. 221-223, 381; and David Browning, El Salvador: Landscape and Society (Oxford: Clarendon Press, 1971), pp. 260-261, as sources for explanation of the terminology used in reference to the labor force during this period. 
pressures were created that would lead to political unrest. Indigenous communities were re-established, and this, coupled with the hacienda system, led to a gradual population increase. Extensive cultivation of indigo led to a necessity to import goods, and the Audiencia's laissezfaire policy permitted even greater accumulation of wealth than had occurred with cocoa.

The economic cycle that began with the cultivation of indigo flourished for over a century. By the late eighteenth century between 300 and 400 families controlled the political and economic life of El Salvador and, as the rumblings of the independence movement began, four forms of land owner ship had emerged in the country. Despite the encroachments of the crown, a large percentage of the land was held by the Indians or mestizos in communal lands or ejidos. Between one-quarter and one-third of the total land area was divided among large Spanish-owned haciendas with the average size of 800 hectares (nearly 2,000 acres); much of the remaining land was in the hands of small property owners. Finally, there were the squatters who had been pushed off their small plots as the haciendas expanded and who simply occupied whatever piece of earth they could find.

16

Gibson, Spain in America, p. 94, describes Audiencias as administrative entities under the Spanish viceroyalties. 17 Montgomery, Revolution in El Salvador, p. 37. 
As land ownership became increasingly concentrated in fewer hands, the ethnic composition of the country was also rapidly changing. At the beginning of the seventeenth century the country was perhaps 85 percent indigenous, 10 percent mestizo and 5 percent white. By 1780 it was evident that the country was well on its way to becoming a mestizo nation with 60 percent of the population Indian, 31 percent mestizo, and the remainder white.

By the middle of the nineteenth century the demand for indigo on the world market had dramatically declined for three reasons. First, growers found that production and labor costs were far lower in Asia than in Central America. Second, the Civil war in the United States not only reduced that market but created shipping problems as a result of the Union's blockade. Third, and most important, a synthetic dye developed in Germany wiped out the remunerative European 19

market. This set up the circumstances for the emergence of El Salvador's third economic cycle: coffee.

Coffee culture found a natural environment in El Salvador, and its position as the leading coffee producer of Central America began under President Gerardo Barrios in the early 1860s. El Salvador then capitalized on the advantages of a terrain that facilitated transportation, and 18 19

Ibid., p. 38

Ibid., p. 40 . 
on a low-cost labor force. Most of the country is hilly and therefore subject to erosion problems with most annual crops except for trees. Of the tree crops, the distribution of rainfall and other natural conditions favor coffee. When a substitute for indigo was sought in the early nineteenth century and the government distributed free young plants of a number of commercial crops, only coffee prospered. Coffee trees do not produce for five years after planting, so it was necessary for prospective planters to have either the capital on which to live during those years or access to credit. The planters in El Salvador in the best position for either of these things were the prosperous hacendados who had already made a fortune from indigo.

The rise of coffee to replace indigo created some changes in the ruling class of El Salvador. A number of those families with wealth based on indigo faded into the background, while others, who early saw the opportunity presented by coffee, took their place. The latter planters came primarily from the ranks of foreign immigrants and urban middle classes, not from rural origins, although many of the wealthy hacendados made the transition from one monocrop to another.

The prosperity of the nation and, most of all, the affluence of the coffee producers, increased tremendously as the value of coffee exports moved higher. By 1881 the 
export value had reached $\$ 2.9 \mathrm{million}$. This increased to $\$ 21.9$ million in 1916. From constituting approximately 50 percent of exports in 1882, coffee dominated the economy by the turn of the century. It made up 76 percent of exports by 1901 and remained the primary export to the current time. It reached a high of 95.5 percent in 1931.

The transformation in land-tenure structures was accompanied by equally significant changes in the nature of state and political power relations, with force becoming necessary to consolidate and maintain the position of the coffee export oligarchy in rural areas.

The use of force to guarantee control of the land and to insure adequate supplies of labor created a need to revamp the judicial system to meet the needs of the landlords. After the abolition of tierras comunales (communal lands) in the period starting in 1871, the government specifically designed legislation to guarantee a constant supply of cheap labor. This was accomplished by recruiting the dispossessed for work on the coffee estates. Specifically, the new laws enabled private property-owners to expel tenants and squatters from their estates. The agents of expulsion were the local civil and military authorities. David Browning explained how the processed worked: 
'Agricultural judges' were appointed in each village and these officials had to keep lists of all day workers, arrange for the capture of those who left an estate before fulfilling their obligations, and to visit private estates regularly to check the need for workers. In this task the local officials were supported by the army. 21

In summary, the shape of El Salvador's contemporary socioeconomic and political power structure, and its cultural organization, were set in place during the three economic cycles culminating with the coffee culture extending from the 1880 s into the Great Depression. These consisted of a single-crop primary export economy, a narrow ruling class which concentrated land and export earnings into its own hands, and as a consequence blocked the development of a strong national economy, and a political system that relied on coercion for maintaining the dominant position of export interests and therefore encouraged the exaggerated development of the military and police institutions of the state and the parallel weak development of political institutions to generate consensus, particularly in the rural areas. 


\section{CHAPTER II}

\section{BIRTH OF THE MILITARY INSTITUTION}

Rising unrest among the Salvadorean peasant population over the issues of land dispossession and forced labor resulted in periodic rebellions against the patrones, who assumed the task of dealing with these recalcitrant peasants. The methods employed to quell the rebellions that took place during much of the nineteenth century entailed the use of private armies. Elements of these armies would evolve as the Rural Police and the Mounted Police, created by decrees in 1884 and 1889,22 respectively, in the western departments of Ahuachapán, Sonsonate, and Santa Ana. An 1895 decree extended these to forces over the entire country.

The first genuinely Salvadorean army was formed by General Manuel Arce, the first president of the Central American federation, in 1824. The country was being overrun by free-booting units that had been engaged in combatting the incursions of the army of Mexican Emperor Agustín de Iturbide. Arce consolidated these widely scattered units and placed them under a centralized command. After the 
disintegration of the federation, this became the nucleus of the army of the newly independent nation. The date of the formal unification, May 7 , is still celebrated as the country's armed forces day, called the Day of the Salvadorean Soldier.

The army progressed steadily over the years, developing and growing in professional competence and usually acquitting itself commendably in frequent local wars and actions. Foreign influences made themselves felt from the outset as succeeding presidents brought in foreign military missions and advisors. President Gerardo Barrios (1858-63) brought in a French military mission that effected a drastic army reorganization and instituted a number of innovations, including the establishment of a military school for officers. The president also used advisors from Colombia to improve the conduct, appearance, and discipline of the army and militia.

French and Spanish officers served as a cadre during the following years and spent extended periods training infantry, cavalry, and artillery units. Because El Salvador lived under constant fear of invasion during this time, the attention of the army was directed to national security. This left the task of maintaining order to what would become

\section{3}

Howard I. Blutstein and others, Area Handbook for El Salvador (Washington, D.C.: U.S. Gov't Printing Office, 1971), p. 194 . 
known as the security forces. El Salvador's government did not use the national army to control the people until the late twentieth century.

The rural police eventually became known as the National Police, and in 1912 El Salvador established a National Guard patterned after the Spanish National Guard and formed and trained by Spanish officers. A third security force, the Treasury Police, was created in 1936. These early security corps did not prove to be viable forces when the changes in power between liberal and conservative elements of the political scene were being effected. Necessary force generally came from sympathetic neighboring countries. 24

Conservatives battled Liberals for control of El Salvador for the last half of the nineteenth century. Agitation quieted somewhat during the longer administrations of Francisco Dueñas (1863-71), who was backed by Conservatives in Guatemala, and Rafael Zaldivar (1876-85), a protégé of Dueñas who managed to maintain friendly relations with Liberal administrations in all the bordering republics.

The economic stability of the coffee boom stabilized El Salvador's political scene from the end of Zaldivar's reign 24 25 Ibid., pp. 202-104. White, El Salvador, p. 89. 
until 1931, with international conflicts being less frequent and the presidential succession more regular. Relative absence from turmoil did not bring democracy during this time, however, because each president's successor was either a close friend or relative and all power remained in the hands of the wealthy.

A step toward democracy in 1931 led to a military dictatorship instead and established a pattern which would last into the 1980s. Pío Romero Bosque, president from 1927 to 1931, decided not to exercise control of the election of his successor. When no candidate won a majority of the popular vote, congress chose Arturo Araujo. He did not last out the year, being overthrown on December 2, 1931.

Araujo had taken office on March 1, 1931. He represented the Partido Laborista [Labor Party] and was supported by the majority of the urban middle and working classes, the recently organized Communist Party, and peasants. The Partido Laborista had promised agrarian reform and industrialization in order to relieve the socioeconomic crisis brought on by the Depression, but unfortunately Araujo and his administration were not capable

\section{6}

27

Ibid., p. 99.

Robert J. Alexander, Communism in Latin America (New Brunswick: Rutgers University Press, 1957), pp. 366-371. The author traces Communism in El Salvador from 1926 to 1956, citing the revolutionary nature of its doctrine there. 
of formulating and implementing policies to deal with these basic problems. As a consequence, his popular base quickly disintegrated, and nine months later he was deposed by a group of young officers who quickly turned power over to his appointed Vice President, General Maximiliano Hernández Martínez.

Hernández Martínez and the top level of the military hierarchy rapidly consolidated power and established a program which was designed to establish political order and permit recuperation of the country's economy. That meant coffee production and the defense of the export oligarchy of the coffee producers. It also contributed to the Rebellion of 1932, commonly designated the matanza, or massacre.

Peasant resistance to government programs had a long history in El Salvador, particularly in the late 1880 s. Their eviction from the lands they were farming in the $1870 \mathrm{~s}$ and 1880 s was a result of an expansion of coffee production. This was similar to the situation that had occurred during the indigo boom of the late eighteenth century and was also the case in the 1920s when the same process of export expansion led to a second wave of peasant dispossession and increased political repression in the rural areas.

28

Thomas P. Anderson, Matanza, El Salvador's Communist Revolt of 1932 (Lincoln: University of Nebraska Press, 1971). Much information regarding this period was drawn from this book. 
With the onset of the Great Depression the demand for coffee on the international market collapsed and prices fell dramatically. With coffee no longer in demand, the limited possibilities of the peasantry to obtain even temporary work faded away. First they had lost their land, and now they lost their opportunity to work. Peasant response was predictable.

An extensive revolt broke out in the coffee-producing areas of the western and central highlands on January 20, 1932. The revolt was actually planned for January 22 and was designed to give its planners, the Communist Party, immediate seizure of power. Unfortunately for the Communists, the plot was discovered and the Party leaders were arrested.

Hernández Martínez found out what was happening through the Jorge Ubico government in Guatemala, which had inadvertently received information and documents concerning the revolutionaries' activities. Martínez moved swiftly against the would-be rebels. On January 18 a state of siege was proclaimed in San Salvador and the principal departments implicated in the revolt plot. The Communist newspaper, Estrella Roja, was suppressed, and its editors, Mario Zapata and Alfonso Luna, were jailed. The principal Communist military leader, Agustín P. Martí, was captured. 
Martínez ruthlessly suppressed the rebellion by the campesinos, and seventy-two hours after the revolt began the army had smashed all opposition. Thousands of peasants were killed and virtually all the leaders of the Communist Party were captured, court-martialed, and shot. Estimates of the number who died during this period vary widely, but 15,000 to 20,000 is likely. The figure of 30,000 is often used by the political left.

The successful subjugation of the rebellion marked the rise to political power of the military in El Salvador. The oligarchy ceased governing directly and withdrew from the political arena at that time, content to let the military do its bidding. Since then a symbiotic relationship has existed between the military and the elite. The latter's patronage has allowed the military the opportunity for education, power, and wealth. Conversely, the oligarchy has needed the military to protect its wealth and power.

Just as a cyclical pattern of economic development had evolved in the colonial period, so a cyclical pattern emerged in El Salvador's political life after 1932. Where the first pattern had served to consolidate economic power 30 31 White, El Salvador, p. 101.

Edwin Lieuwen, Generals vs. Presidents: NeoMilitarism in Latin America (New York: Frederick A. Praeger, 1964), p. 91. 
in a few hands, those of the oligarchy, the second pattern served to perpetuate political power in other hands: those of the army. Meanwhile, the economic situation continued unchanged for the masses, and the reforms that occurred in no way affected the sources and distribution of wealth or the control of the national economy.

The political cycles operated as follows:

1. Golpe de estado, led by progressive officers

2. Promulgation of various reforms

3. Re-emergence, within the army, of the most conservative faction

4. consolidation of power

5. reaction from two quarters: the public, and, more important, a progressive faction within the army officer corps, resulting in

6. Golpe de estado.

Throughout the political cycles it was obvious that maintenance of the status quo was the object of the military. In each political cycle a time came when the government, feeling itself under siege, would increasingly label all dissent "subversive" and the work of "communists." These were also the favorite labels of the oligarchy for anyone in El Salvador who advocated any social or economic change that would, in any measure, affect its economic interests adversely. 
Each political cycle brought some measure of social and economic reform, although it was never enough either to deal adequately with El Salvador's growing numbers of poor people or to tamper with the economic status quo. Throughout the decades following the assumption of power by the military in 1931 two goals remained paramount. One was the protection of the interests of the oligarchy, and the second was the preservation of the institution of the army.

An examination of the six political cycles that occurred between December 1932 and October 1979 reveals that Salvadorean politics indeed had certain abiding characteristics which were distinctive of El Salvador's peculiar political, social and economic situation. Throughout these cycles there were certain constants that emerged with Hernández Martínez's regime. The first was the establishment of the official party.

Created by Martínez and named "Pro-patria" (for the homeland), the official party was not a traditional political party. Salvadorean political scientist Ruben Zamora noted that although the party occasionally fulfilled some of the traditional functions of a political party, in fact its real purpose was to be an instrument of social control. Before 1932 the oligarchy controlled the people through two mechanisms: the security forces that operated as personal instruments of repression, and, more subtly, 
32

through compadrazgo, a social institution that created family-like ties between patrón and campesino. The mechanisms of compadrazgo passed to the state after 1932. The official party did indeed function as the personal instrument of Martínez, who kept the peasants in line during the 1930s through a highly personalistic style of rule.

The second constant in Salvadorean life was the use of repression to maintain order when persuasion failed. The security forces continued to serve the needs of the oligarchy and were particularly effective in the countryside. Both security forces and army units were used in the cities whenever demonstrations by university students or labor unions threatened domestic tranquility. As years passed, the techniques of repression became more sophisticated, as many leftist leaders would learn firsthand in the 1960 s and 1970s.

In each political cycle, a time came when the government, feeling itself under siege, would, with increasing frequency and vigor, label all dissent "subversive" and the work of "communists." These were also the favorite labels of the oligarchy for anyone in $\mathrm{El}$ Salvador who advocated any social or economic change that would in any measure affect its economic interests

32

Montgomery, Revolution in El Salvador, p. 56. The dictionary defines this term as "relation of a godfather to the parents of a child." 
adversely. Over the years the labels have applied to army officers, members of the centrist political factions, church leaders, labor unions, and to openly leftist organizations. Between December 1931, with the rise to power of Maximiliano Hernández Martínez, and october 1979, when a junta replaced Carlos Humberto Romero as head of the government, El Salvador experienced the expression of continuismo through the medium of six cycles of political domination by a military figure or figures. The consistency of the pattern of the six cycles indicates the overwhelming political dominance of the military in $E l$ Salvador. It also demonstrates the fact that political intervention by the military in El Salvador, as well as in many other countries in Latin America, does not seem to have the effect of overhauling the power system of the society. Rather, under military governments, holders of important power capabilities in the society are assured that their position in the society will not be endangered. 


\section{CHAPTER III}

THE FIRST THREE CYCLES: THE LONGEST AND THE SHORTEST

The first three political cycles of military dominance in Salvadorean politics provided both the longest and shortest periods that reflected the cyclical mechanism. Maximiliano Hernández Martínez, described by Alastair White as an "accomplished serendipitist" 33 and by Mario Rodríguez as holding people as holding people spellbound with "crackpot divinations," governed the country for 13 years $(1931-1948)$. His successor, General Salvador Castañeda Castro, lasted less than four years (1945-1948).

Martínez moved quickly and decisively to consolidate his power. In addition to founding the official party, his government developed four means of keeping the people in line. First, it effected an administrative reorganization throughout the country that centralized decision making and all public works and services. Second, Martínez further consolidated this control by replacing civilians with military officers at the local and national levels. Third,

\section{3} 34

White, El Salvador, p. 99. Mario Rodríguez, Central America (Englewood Cliffs: Prentice Hall, Inc., 1965), p. 128 . 
all political organizations were banned. Fourth, labor unions were discouraged on the grounds that they were subversive.

Meanwhile, Martínez made some economic concessions. First, in March 1932, he demonstrated his willingness to depart from the norm by declaring a moratorium on debts, with the stipulation that debtors would not be prosecuted. He also devalued the colón, which has remained at the rate of $\& 2.5$ to the U.S. dollar since 1944. In 1933 he founded Mejoramiento Social [Social Improvement], a general-purpose government institution to help raise the standard of living for the poor. In 1936, the government authorized the buying of land to redistribute to small farmers who would pay by 35 installment.

Dependence on a single crop continued as before, with government policy directed toward protecting the interests of the coffee growers. Laws were designed, however, to discourage mechanization, and investment was encouraged only in industries that did not threaten artisan production, such 36

as shoemaking. There was fear that industrialization would destroy such crafts and revive the alliance between peasants and workers that had led to the 1932 insurrection. As a protectionist measure it seems partial, too late, and 35 36

Browning, El Salvador, p. 280 . White, El Salvador, p. 102. 
ill-conceived, since it made no provision for the gradual transformation of handicraft production into a competitive modern industry. It was, however, a concession to the economic aspirations of at least a section of the poor, and for that Martínez is remembered with a certain amount of gratitude.

When the Central Reserve Bank was created in 1934 to help nationalize the country's economy, private banks were barred from issuing currency. However, the oligarchy controlled the bank and insured that the coffee growers' interests would be protected by guaranteeing that their land would not be foreclosed and that sufficient capital would be available for the further development of coffee production.

A year after the Central Bank was founded, Martínez took steps to provide credit for agricultural operations of different sizes. Banco Hipotecario [mortgage bank] was established in 1935 for large-scale operations and the Cajas de Crédito Rural in 1943 for the small farmer or campesino. Other economic policies of the regime included nationalization of all public utility companies and assertion of the right of eminent domain over municipal power companies. Following compensation to the previous

\section{7} 38

Montgomery, Revolution in El Salvador, p. 58. White, El Salvador, p. 102. 
owners, the new National Electricity Commission assumed responsibility for the operation of the utilities.

In the long run, Martínez's policies did not significantly help the small businesses recover from the depression, nor did the establishment of new businesses flourish. They bred a certain amount of discontent among the Salvadorean elite. However, a modus vivendi developed between the Martínez military regime and the civilian oligarchy at that time which survived through all subsequent regimes. The military occupied the presidency and most high governmental offices. Key positions in the economy were occupied by influential civilians, particularly in the coffee industry.

Centralization of the government by Martínez provided a nationalistic foundation for future governments, which was accomplished by various means: the control of a modernized military organization with new weapons that made dissidents think twice before challenging them; press censorship and the use of government spies to "encourage" mass conformity to governmental programs; the exile or imprisonment of the opposition, oftentimes liquidated while trying to escape; and "exemplary punishment," as demonstrated by the execution of large numbers of persons suspected of being involved in 
the rebellion in 1932.

When there is a difference of opinion in El Salvador over the appropriate balance of concession or repression, there are supporters on both sides among the civilian and the military. This includes those occasions when a president is thought to be going too far in one direction or another, and a movement is coordinated to oust him. Three times between 1935 and 1939 there were plots to overthrow the Martlnez regime. In 1935 the would-be golpistas were shot. The major plot occurred in 1938 when Colonel Asencio Menéndez led a plot to depose Martínez, who had announced his intention to have himself re-elected. The plot was 41

uncovered and the main conspirators exiled.

In the winter of 1943-44 Salvadoreans in all walks of life were insulted by the dictator's brutal reprisals against the opposition and his bold attempt to perpetuate his rule by calling a new constituent assembly for February 1944. The economy was on the upswing after the country had entered the Second World War immediately after Pearl Harbor, and Martínez's repressive regime came to be seen as less and less desirable or necessary.

40 41

Rodríguez, Central America, p. 128.

Robert Varney Elam, "Appeal to Arms: Army and Politics in El Salvador 1931-1964." Ph.D. dissertation, University of New Mexico, 1968, p. 48, as quoted by Montgomery, Revolution in El Salvador, p. 59. 
On April 2, 1944, disenchanted army officers and increasingly restive members of the bourgeoisie backed a golpe staged by army and air force officers. Martínez, with the support of the National Guard and National Police, survived the revolt and imposed martial law throughout the country. The harsh measures taken against the participators in the revolt were too much for the people. Striking university students were soon joined by high school students, clerks, and professionals. By the end of April the general strike brought the city of San Salvador to a standstill. In a last-ditch attempt to preserve his regime, Martínez attempted to mobilize workers and peasants in an effort to break the strike, but his efforts failed.

The final blow came on May 7, when a student, José Wright, a member of the Salvadorean elite, although an American citizen, was shot dead by a policeman. The following day, upon advice of United States Ambassador Walter Thurston, Maximiliano Hernández Martínez addressed the nation by radio and announced his resignation.

Martínez's abdication of power led to four years of comparative democratic political activity. Between May 8 and October 21, 1944, protagonists from both liberal and conservative factions scrambled for position in anticipation of free elections. This period of political ferment was 
marked by the creation of new political parties and also parties emerging from clandestine activity. Political activity had not been so hectic in the country since the 1931 election. As election day approached, Arturo Romero, a young doctor who had been a civilian leader in the April revolt, was selected as the candidate of the more advanced political groups. 43

Romero's forces were not politically strong enough to sway the conservative political elements, however, and on October 21 Colonel Osmín Aguirre y Salinas, who had been Martínez's Director of National Police, seized power and reestablished a dictatorship along the Martínez lines. Romero was exiled to Costa Rica, and with only minor right-wing candidates left in the field, General Salvador Castañeda Castro, supported by Osmín Aguirre y Salinas and the military, won the forthcoming elections.

Castañeda Castro's government was not as repressive as that of Hernández Martínez, but neither was it inclined to carry on any of the modest economic and social reforms that Martínez had implemented. On the one hand Castañeda Castro instituted a variety of meaningless reforms, and on the other he began limiting the freedom of liberal spokesmen and

\section{3}

Ibid., p. 104; 114. According to White, Romero's public platform, if not his private position, was to protest his preference for "democracy" against "communism"; many saw him as a communist. 
organizations. The latter measure was taken to pacify his conservative colleagues and promote consolidation of his power.

Among his first acts as President was the decision to allow some of the political organizations that had surfaced in the ferment of 1944 to continue. After he formally assumed office in March 1945, he issued a general political amnesty, opened the borders, and undertook a reorganization of the government and the army.

In an extraordinary scheme, shortly after his inauguration Castañeda Castro met with President Juan José Arévalo of Guatemala to discuss the political and economic union of the two countries. Both men were committed to the idea and hoped that their example would promote the adherence of other Central American countries. The two leaders discussed the possibility of a combined banking system as well as declaring an open border and eliminating immigration barriers. El Salvador and Guatemala formally announced their political merger to the United Nations in June 1945, but the new federal government ultimately suffered the fate of its predecessors. 44

Honduras, Nicaragua, and Costa Rica all offered different reasons for not taking the new federation 
seriously; and while these nations offered various excuses for not wanting to join the union, time eroded the relationship of the two partners themselves. Domestic problems distracted them so that by 1947 it was clear that political union in Central America had failed once more. Meanwhile in El Salvador the static stance of Castañeda's regime was demonstrated against by a general strike which closed businesses, transportation, and newspapers in the capitol city of San Salvador. The middle class liberals had envisioned economic and social changes, but the president had responded with diversions. These included a new constitution in 1945 that was virtually identical to that of 1886 , a program of public works providing for paving streets and building a bridge over the Lempa River, and various social programs in the area of health hygiene. These efforts emphasized construction of facilities that would produce the greatest political 45 return.

Castaneda Castro contributed to his own demise by attempting to isolate the more progressive elements within the armed forces by shipping a large number of them out of the country for training or service as diplomatic attaches

45

Elam, "Appeal to Arms," p. 122, as quoted by Montgomery, Revolution in El Salvador, p. 62 . 
between 1945 and 1948 . $^{46}$ During their absence an aura of depression prevailed among Salvadoreans, bred primarily by Castaneda's politics of stagnation. When he made known his intention to prolong his period of office, he was overthrown by a faction of reform-conscious military men.

On December 13, 1948, the National Assembly had met to call for the formation of a new constitutional assembly that would permit Castañeda Castro to succeed himself. The next day fighting broke out in San Salvador between National Police loyal to the president and younger officers in El Zapote barracks next to the Casa Presidencial. The rebels involved in this golpe took over the National Police headquarters where Castañeda Castro had taken refuge, and it took little time after that to convince him that his career as president was at an end.

Castañeda's downfall led to a third cycle in the evolution of Salvadorean repressive politics. The Revolutionary Council, whose identities had been a mystery, proclaimed its control of the government later in the day of the December 13 outbreak. Lieutenant Manuel de Jesús Córdova assumed his role as a key member of the council of three young military men and two civilians. The group

46 47

Montgomery, Revolution in El Salvador, p. 62. Ibid., p. 62, and White, El Salvador, p. 105. 
immediately asserted a break with the past by ending the state of siege brought on by the revolt, declaring an amnesty and announcing the restoration of political rights. Like others before it, the council proclaimed its determination to initiate needed economic and social reforms. It also affirmed its determination to remove the army from politics and to make that institution a defender of the constitution. In spite of the unpopularity of exPresident Castañeda, these announcements were greeted with less than overwhelming enthusiasm by the Salvadorean people. They had heard it all before.

Undaunted by popular apathy, the Revolutionary Council acted quickly to institutionalize its break with the past. The council abrogated the constitution and reserved all legislative and executive powers to itself. It called for a freely elected constitutional assembly. The council then moved against former government officials and civilians, sealing their bank accounts and barring them from leaving the country or seeking refuge in foreign embassies.

The council maintained itself in power for fourteen months. It created a momentum in its first weeks that demonstrated its commitment to both institutional and social

48 49 Ibid., pp. 129-130. Montgomery, Revolution in El Salvador, p. 65. 
change, yet while this momentum was building the membership of the council was changing. Less than a month after the golpe, Córdova resigned from the council and went into exile in Honduras; and Major Oscar Osorio, another member, took over.

The motivation of the officer corps during this time was complex. As in 1944, there were two groups among the rebels. One group recognized that some moderate reforms had to come in order to preserve peace, stability, and the institutions of the army. The second group was committed to reform for its own sake. Both groups undoubtedly felt pressured by developments in Guatemala where a 1944 revolt had succeeded and a progressive government headed by the army launched significant social and economic reforms.

Nine months after the coup a new election law took effect and banned political parties based on religion, sex, class, foreign financial support, or communist affiliation. In January 1950 the council called for a national election in March to select a constitutional assembly and a president. It also established an autonomous consejo central elección [Central Election Council, CCE), charged with collecting and counting the votes. Other

50

51

Ibid., p. 65.

Elam, "appeal to Arms," p. 144, as quoted in Montgomery, Revolution in El Salvador, p. 65 . 
decrees granted women's suffrage and instituted the secret ballot.

Oscar Osorio resigned from the Revolutionary Council prior to the political campaign in the Fall of 1949 to form the newest official party, the Partido Revolucionario de Unión Democrática [Revolutionary Party of Democratic 52 Unification, or PRUD]. Orsorio then became its candidate for presidency and easily attained office, winning 60 percent of the vote. His party captured a decisive majority in the Congressional Assembly.

orsorio was inaugurated in september 1950.53 That same month the Assembly issued a new constitution, thus fulfilling one of the Revolutionary Council's original promises. Under the constitution the army acquired a new name, the Fuerzas Armadas [Armed Forces], with its strength set at 3,000 men. Neither the number nor the name, however, included the security forces, which retained separate identities.

The successful system implanted by Osorio was sufficiently open and flexible to allow an incumbent

52 53 Rodríguez, Central America, p. 57.

Montgomery, Revolution in El Salvador, $p_{\text {: }} 65$, and Rodríguez, Centrai America, p. 37, differ on' this date, with Rodríguez citing March as the month Osorio took over. 54 Montgomery, Revolution in El Salvador, p. 65. 
president to judge public reaction to his mix of concession and repression with regard to the masses. He still repressed open revolutionaries, but provided an opportunity for those who were content merely to advocate milder reforms to do so through opposition political parties.

Once inaugurated, Osorio wasted no time before embarking on a series of public works and other programs intended to encourage industry and trade, increase production, and diversity agriculture. The programs included housing construction, health care, and sanitation. Labor unions were legalized in 1951, although demands for agricultural unions were ignored. A year later collective bargaining was instituted under government regulation. When the oligarchy complained about too many concessions to the masses, the government reminded it of the "communist threat" in neighboring Guatemala, where a populist, socialist military regime under Colonel Jacobo Arbenz was moving even faster with economic and social reforms.

The developmentalist policies adopted by the Osorio regime to encourage the growth and modernization of the industrial sector constituted an improvement over the efforts of preceding regimes but unfortunately tended to achieve only an expansion of job opportunities for a new salaried middle sector. In attempting or appearing to 
introduce modern government provision for social development, they tended to create a relatively privileged sector within the working class, those with access to such innovations as social security, collective wage-bargaining through the legal unions, and the government urban housing and rural land settlement schemes.

The fact remains that progress occurred during Osorio's administration. Many laws passed by the Martínez regime in the 1930 s were scrapped. Other measures that promoted the growth of the economy included: strong incentive in the form of tax breaks; repeal of laws restricting the process of capital accumulation; income taxes on a larger proportion of personal income (a measure that affected the small but growing middle sector); and an increase in the tax on the exportation of coffee. The state embarked on a roadbuilding program and constructed the November 5 th Dam on the Lempa river, which boosted energy output dramatically while cutting the cost of electricity by 25 percent. It also built the Puente de oro [Bridge of Gold], so named because of its high cost, a 2,600 foot ( 800 meter) span across the Lempa River on the Litoral Highway in south central El Salvador.

55 James W. Wilkie, Statistics and National Policy (Los Angeles: University of California Media Production, 1974), p. 221, for example, consumption of electricity rose from 19 kilowatt hours per capita in 1937 to $78 \mathrm{Kwh}$. in 1957. 
Many of the tax breaks and similar measures began in 1949 and have been extended through each succeeding administration. Each president wished to have his regime marked with some new measure designed to increase his popularity. Likewise, each president usually carried out in broad outline the measures initiated by his predecessor without upsetting the fundamental control of the oligarchy over the economy. Increased coffee production and skyrocketing prices facilitated newly encouraged 56

industrialization. The oligarchy had to do something with its profits.

President Osorio pursued an independent policy of opposition to the Communist threat in El Salvador. Fearing presence of Communists in his country, perhaps linked to those in Guatemala, he declared martial law in 1952 and subsequently banned all "subversives" from participating in politics. He had also promised that the army would be removed from politics. This was not to be. The regime was loath to allow any significant opposition, and in both 1952 and 1954 it so restricted the activities of opposition parties in the Assembly election campaigns that they withdrew their candidates. The military and the oligarchy

56

Ibid., p. 268. El Salvador's balance of trade rose from three million dollars in 1947 to 21 million dollars in 1950 . 
agreed that the radical elements in El Salvador would be given no opportunity to gain a toehold in the country's political future.

By the mid-1950s army officers held a majority of the important governmental offices in El Salvador, including most of the departmental governorships and key offices in the new institutes that had been established to develop and carry out various reforms. After some internal infighting Osorio, who had actually chosen a civilian to succeed him as president, reneged and announced Lieutenant José María Lemus as the PRUD candidate. In the election that followed, Lemus encountered no real opposition and won easily, garnering an announced 93 percent of the votes.

Lemus took office in September 1956 and, following the accepted pattern, undertook to continue his predecessor's welfare program without disturbing the structure of Salvadorean society. He continued several public works projects already underway, notably improvement of the port facilities at Acajutla and construction of the new Pacific coastal highway, and tried to emphasize the economic rather than the political aspects of his incumbency.

Lemus had begun his administration on a concessionary note. He declared a general amnesty for political

57

Blutstein, Area Handbook for El Salvador, p. 19. 
prisoners, he voided a number of repressive laws that had been passed by earlier regimes, and he selected men of recognized probity and ability for his cabinet. Economic conditions were working against him, however. A steady decline in the price of coffee and cotton brought economic hardship both to the government and to a sizable sector of the population, and this was reflected in growing political unrest and dissatisfaction.

By 1958 the opposition was becoming more militant and clamorous and was making demands that could not be ignored. There was particularly strong agitation for a new electoral law that would ensure honest counting of votes and minority representation in the Legislative Assembly. The following year the all-PRUD assembly enacted a new electoral law, but it was framed in such a way that it was almost impossible for any opposition to make itself felt.

As election time neared, violence increased, and there were strikes and street demonstrations against the president, who was accused of governing outside the law. An assassination attempt failed, and Lemus reacted by becoming increasingly harsh and dictatorial. Attributing all his troubles to Communists and reactionaries, he banned free expression, forbade free assembly, and imprisoned opponents on scant evidence and without trial. In October 1960 Lemus was deposed by a group of leftist officers and civilians and 
deported to Costa Rica. The new government, which was considered pro-Castroite, was too radical for the army, however, and in January 1961 it in turn was overthrown by a countercoup led by a group of conservative officers.

The leaders of the countercoup blamed both Osorio and Lemus for the leftist orientation of the previous junta. The new directorate, which consisted of three civilians and two military men, assumed power on January 24, 1961. The next president, Colonel Julio Adalberto Rivera emerged from its ranks. Closely identified with the United States, the new government maintained order during the critical year 1961 and prepared for elections in 1962 . 


\section{CHAPTER IV}

THE FINAL THREE CYCLES: DETERIORATION OF THE STATUS QUO

The new junta, headed by Lieutenant Colonel Rivera, promised a speedy return to constitutional government and early elections. Recognizing the need to consolidate its power, it turned its immediate attention to curing the social ills that were besetting the country. In the first nine months of its rule, the junta enacted over 300 laws, most of them dealing with problems created by the country's social inequities.

In January 1962 a new constitution was adopted, replacing the 1950 charter. Rivera resigned from the junta in order to campaign for the presidency and devote his time to ensuring the effectiveness of his newly organized party, the National Conciliation Party [Partido de Conciliación Nacional, PCN). A provisional president, Eusebio Cordón, a civilian physician, was appointed to serve until the inauguration of a new executive, and elections were held in April. As expected, Rivera won the presidency, his only opposition being a donkey which ran under the banner of the Asociación General de Estudiantes Universitarios

Salvadoreños [General Association of Salvadorean University 
Students, AGUES], the student political organization that had played a very significant role in leading mass protests 58

during turbulent periods of the era.

Rivera's regime continued the pattern laid down by Osorio, achieving stability by adopting a flexible policy of varying the degree and the form of repression and economic concession according to the political exigencies of the moment. The policy was also made more sensitive by allowing more freedom of political activity in forms judged to be innocuous, while left-wing expansion in the countryside, for example, was still rigidly repressed. Over and above the temporary cycles of relaxation and retightening of control, the political policy tended to ease with time as the economy grew and gave rise to a new middle sector. The

"revolutionaries," meanwhile, increasingly occupied themselves either in pursuing partial economic gains for a section of the working class through trade union organization and wage claims, or in internal politicking at the national university. The political situation during that time might be described as the result of a successful strategy on the part of the ruling class to incorporate its 58 59

Montgomery, Revolution in El Salvador, p. 74.

White, El Salvador, pp. 213-214, describes the Partido Comunista Salvadoreño as rather ineffective during "normal" periods of the political cycles in El Salvador, stating that "When a communist earns 400 dollars a month he no longer thinks of Sierra Maestras..." 
opponents into the formal political system without allowing them to have any really significant effect on the outcome.

Measured by some indicators, President Rivera succeeded not only in reversing the economic decline that $\mathrm{El}$ Salvador endured during the late 1950s, but in setting the country on an economic course that created "boom" conditions. For example, the annual rate of growth of value added in the industrial sector between 1962 and 1967 was as much as 11.7 percent. In Guatemala, in comparison, the annual rate of growth of value during the same period was 3.6 percent. In fact, the conditions that produced the "boom" and "bust" under Presidents Osorio and Lemus remained unchanged.

The substitute for agrarian reform during this time was the economic integration of Central America, resulting in the creation of the Mercado Común Centroamericano [Central American Common Market, CACM], referred to in Central America as the Mercomún, or MCC. CACM actually went into effect on June 3, 1961, and its impact was soon apparent. Inter-regional trade increased 32 percent between 1962 and 1968, and the increase averaged 26 percent between 1960 and 1972. 61 The nature of the goods being traded changed from unprocessed agricultural products to nondurable consumer

60 61 Wilkie, Statistics and National Policy, p. 395. Montgomery, Revolution in El Salvador, p. 76. 
goods. The nature of industry also shifted from import substitution to industry for export; that is, the assembly or packing of imported components.

The economic reforms of the 1960 s began attracting both domestic and foreign investment. The Alianza para el Progreso [Alliance for Progress] initiated by the John F. Kennedy administration helped create the "boom" time aura through the allocation of funds for housing, school construction, health facilities, and water and sewage projects. The army began providing manpower for various public construction projects which, while demonstrating that the army was working for the people, also denied hundreds of civilian jobs in a country where the unemployment rate ranged between 30 and 57 percent.

In May 1965 the Rivera government enacted a minimum wage law for agricultural workers, ostensibly to bring a new, higher standard of living for Salvadorean peasants. Its effect was devastating to many thousands of people, however, because the colono or aparcero no longer received food and a milpa [portion of land] as part of his wages. He became merely a laborer whose sole connection with the

\section{2}

63

Ibid., p. 78 .

White, El Salvador, pp. 118-119. The colono's income was reduced further by the fact that his wife and children were no longer employed because they couldn't do a man's share of the work. 
property that he worked on was the wage paid to him by the owner. The 1971 census recorded a decline during the preceding decade in the number of colonos from 55,769 to 17,019. At the same time, the number of landless campesinos increased from 30,451 (11.8 percent of all rural Salvadoreans) in 1961 to 112,108 (29.1 percent) ten years later. By 1975 the figures had climbed again, to 166,922 landless people ( 40.9 percent).

Problems emerged in the last years of Rivera's regime that further depressed the economy and added to the plight of the masses. World prices for coffee dropped, disease and drought severely affected the cotton crop, and sugar cane surpluses increased as world demand plummeted. Private investment declined as budget and international payment deficits mounted. The government was forced to curtail many public works projects and social welfare programs, and unemployment grew. These conditions bred popular unrest as the unemployed migrated to the cities and took to the streets for the first time since 1959 to demand relief.

President Rivera reached the end of his term in 1967 without major incident, however, and the presidential

64

Montgomery, Revolution in El Salvador, p. 80. election held in March was considered one of the most honest. 65

Wilkie, Statistics and National Policy, p. 268. Salvadorean balance of trade reached a minus $\$ 31$ million in 1966 . 
election held in March was considered one of the most honest ever held in the country. Colonel Fidel sánchez Hernández, Rivera's hand-picked successor, represented the Partido de Conciliación Nacional [Party of National Conciliation, PCN]. Although faced with contestants from several other parties, the most prominent of which were the partido Acción Renovadora [The Party of Renovating Action, PAR], the Partido Demócrata Cristiano [Christian Democratic Party, PDC], and the Partido Popular Salvadoreño [Salvadorean Popular Party, PPS], Colonel Sanchez won 54.4 percent of the votes and took office on July $1,1967$. 66

Sánchez Hernández inherited the economic woes of the country. Labor unions joined the protest of the unemployed, and many workers and teachers went on strike. Sánchez responded by naming a colonel as minister of labor and charging that the unrest was communist-inspired.

Meanwhile the army began demanding a larger budget, and new equipment began receiving "counterinsurgency" training that had been offered by the United States in the mid-1960s. The growing political unrest in El Salvador and the restiveness in the army, coupled with the intraregional

66

Montgomery, Revolution in El Salvador, p. 81. The outcome of this election was surprising because the PDC garnered 21.6 percent of the vote and the PAR 14.4 percent, demonstrating gathering strength of opposition parties. White, El Salvador, p. 203, states that PAR was outlawed after the election. 
economic issues, provided sánchez with all the excuses he needed to invade Honduras on July 14, 1969, starting the socalled "Soccer War."

Honduras had dispossessed thousands of Salvadoreans, many of them second generation immigrants, from land they had been tilling along the border in Honduran territory. The action was taken in accordance with a new Honduran agrarian reform law, but in fact was a culmination of differences that had built up between the two countries since Independence days. These differences included a centuries-old border dispute, what Honduran leaders perceived as an inequality in balance of trade created by CACM, and the presence in Honduras of at least 300,000 Salvadorean settlers.

The war lasted 100 hours and left several thousand dead and thousands of Salvadoreans homeless. It was dubbed the "Soccer War" by foreign journalists because it followed a series of bitterly contested games between the two countries during the qualifying rounds for the 1969 World Cup. It was finally stopped after five days of furious fighting by the formal intercession of the Organization of American States,

67

G. Pope Atkins, Latin America in the International Political System (New York: The Free Press, 1977), p. 207. White, El Salvador, p. 188. Montgomery, Revolution in El Salvador, p. 80. Thomas P. Anderson, The War of the Dispossessed: Honduras and El Salvador, 1964 (Lincoln: University of Nebraska Press, 1981), pp. 95-96. These authors all add to the picture of the war. 
enforced by pressure from the United States.

The "Soccer War" succeeded in temporarily obscuring the Salvadorean economic woes, but in the long run the action only exacerbated the deteriorating economic conditions within the country. The Honduran market, which had accounted for a large part of the sale of Salvadorean goods, was gone. The Pan-American Highway to Nicaragua and Costa Rica was closed for a time; thus, the Central American Common Market disintegrated into a shambles. In addition to this, El Salvador found itself with thousands of landless and jobless citizens from the Honduran dispossession.

The refugee influx, in effect, broke the taboo on the discussion of agrarian reform in El Salvador; and on August 14, 1969, General Sánchez Hernández announced a package of 68 reforms to respond to the crisis. The center piece was a rather vague "democratic program of agrarian reform" which would "focus upon the problem in its totality.. . oriented in an integral manner toward a more just distribution of land and greater agricultural productivity." 69 These proposals were not taken lightly by the country's oligarchy; and, from their perspective, by the early 1970 s the

68 69

White, El Salvador, p. 212.

Stephen Webre, Jose Napoleon Duarte and the Christian Democratic Party in Salvadorean Politics, 1960-1972. (Baton Rouge: Louisiana State University Press, 1979), p. 122. 
political process had run amuck.

Unions organized, students demonstrated, opposition political parties won elections, the Church defended the rights of peasants to organize themselves, and all of these groups demanded agrarian reform. For the oligarchy, the political opening had gone too far.

In this climate of tension, aggravated further by increasing violence and government accusations of the Christian Democratic Party having communist tendencies, the February 1972 presidential election took place. Amid the usual cries of tampering, the official government party, PCN, candidate Colonel Arturo Armando Molina, the chosen successor of General Fidel Sánchez Hernández, obtained a total of 334,600 votes as against the 324,756 accorded to the Christian Democrat opposition candidate, Napoleón Duarte. The difference was so small that it is reasonable to presume that the amount of direct electoral fraud carried out in provincial areas on behalf of the official candidate could have been decisive in assuring his victory.

An attempted golpe followed the announcement of Molina's victory in late March. José Napoleón Duarte, who had run under the banner of the Unión Nacional Opositora [National Opposition Union, UNO], an alliance of opposition parties, threw in his support only after military maneuvers 70 White, El Salvador, p. 252. 
had already begun. The golpe failed, repression was unleashed against the Christian Democrats, and the opening of the political process had come to an abrupt halt. Members of the military and landlord class had been suspicious of the process from its inception. Under the leadership of National Guard Director, General José Alberto Medrano, they had organized the organizacion Democrática Nacionalista [National Democratic Organization, ORDEN] in "semi-secrecy," probably between 1961 and 1965. It was certainly in existence by 1968. ORDEN was established and has continued to operate as a "paramilitary civilian vigilance association composed of many thousands of armed peasants with the ostensible mission of combatting communism and defending 'democratic' values in the Republic's rural 72

areas." The National Guard, which has traditionally functioned as the private army of the landowners, provides counter-guerrilla military training to ORDEN members, many of whom are army reservists. The clientelistic networks established between army officers and recruits and the paternalistic ties which still existed between landlords and some of the rural poor [compadrazgo], were utilized to form an extensive vigilante organization, even before there had been any known guerrilla threat or peasant political

71 72 Ibid., p. 207. Webre, José Napoleón Duarte, p. 162. 
organization in the country. An effort was made to establish units in all the villages of El Salvador. For those who joined it, ORDEN provided some material security through landlord and military protection and favors.

As long as the electoral process appeared viable in El Salvador, the small groups that began to argue that a revolution by the peasant population was necessary, found small audience. After 1972, the audience began to grow as the moderate Christian Democratic Party came under attack by the government because of its broadly-based popular following. In the months following the elections and the coup attempt, most of the PDC leaders, including Jose' Napoleón Duarte, were forced into exile by the repression unleashed by the Molina regime.

In the years after 1972, the Christian Democratic rank and file joined new popular organizations associated with revolutionary forces. The Catholic church also took up the challenge of representing popular interests as the electoral political parties were prevented from functioning. Moreover, the focus of political conflict shifted from the cities to the countryside. For the first time since the massive repression of 1932 , the rural population began to organize under the aegis of the radicalized clergy and the revolutionary armed forces.

Alastair White observed in his 1973 study of El 
Salvador that the years after 1932 were characterized by an erratic oscillation between "concession and repression," with little effort to maintain a balance between the two. White noted that Araujo in 1931 and Menéndez in $1944 \mathrm{fell}$ after making too many concessions to popular demands by the masses; on the other hand, Martínez in 1944, Castañeda in 1948, Lemus in 1960, and Sánchez Hernández in 1972 all went 73

too far in the opposite direction. Molina's goal was to effect a balance.

After the aborted golpe in March 1972 and the inauguration of Arturo Armando Molina, it appeared for a brief time that a balance had been attained, but the year 1972 proved to be divisive. The army-dominated government had increasingly infuriated most of the oligarchy by its modest reform efforts and it had alienated many workers, peasants, and youths by the inadequacy of those reforms. Demands for greater participation in the workplace as well as in the political system threatened to displace the oligarchy as power and resentment towards the military grew.

Molina, whose legitimacy had been threatened by the earlier golpe, sought to reinforce his authority by fighting communism and maintaining law and order. He picked the

73

White, El Salvador, p. 95. 
University of El Salvador as a starting point, asserting that it had fallen into the hands of communists. A National Assembly decree in July 1973 ordered security forces to occupy campuses throughout the country, closing them down until september of that year.

The Salvadorean conservatives approved of Molina's actions with regard to the University, viewing it as a hotbed of revolution. Their views were accurate, but the repressive character of the action contributed to the increasing radicalization of thousands of young Salvadoreans, providing one more reason for them to believe that meaningful social, political, and economic change was impossible under the existing regime.

The San Salvador mayoral election and that of the National Assembly in 1974 virtually repeated the questionable validity of the 1972 results. The Electoral Council never published the official returns, but the government announced that the UNO had won fifteen seats in the Assembly while the official party (PCN) controlled thirty-six.

\section{4}

Webre, José Napoleón Duarte, p. 185; and Montgomery, $\frac{\text { Revolution in El Salvador, p. } 88 \text {. }}{75}$

Montgomery, Revolution in El Salvador, p. 89. Much of the remainder of the chapter utilizes this author's work. 
Following the 1976 election, Molina's regime decreed a modest agrarian "transformation" and nationalized almost 61,000 hectares $(150,670$ acres $)$ in the Departments of Usultán and San Miguel. Most of this transformation zone was either pasture land or planted in cotton, and the aim was to divide it among 12,000 campesino families. This pilot project was called simply the Agrarian Transformation and enjoyed the full support of the United States government. Through the Agency for International Development (AID), the U.S. pledged $\$ 1.2$ million in loans for the agrarian reform. The decree followed a 1974 Salvadorean law that permitted, under certain conditions, the forced rental or even expropriation of fallow or insufficiently exploited land and a 1975 law that created the Instituto Salvadoreño Transformación Agrario [Salvadorean Institute of Agrarian Transformation, ISTA]. The oligarchy vehemently protested these laws, but failed in an attempt to have them struck down in court. When the transformation zone was established, the oligarchy launched a massive opposition campaign through various interest groups such as the Asociación Nacional de Empresa Privada [National Association for Private Enterprise, ANEP].

76 Jenny Pearce, Under the Eagle (Boston: South End Press, 1981), p. 217. 
ANEP insisted it "was not against agrarian transformation," but charged that this particular project llike all others 77

before it) was precipitous.

The oligarchy utilized campos pagados [paid advertisements] and other devices to fight the reforms, and when everything else proved ineffective, relied on the Minister of Defense, Carlos Humberto Romero, a man of mixed loyalties, to bail them out. Romero had been chosen by Molina as his successor, with the understanding that he would support the agrarian reform. Instead, Romero threatened Molina with a golpe de estado if the agrarian reform went ahead. Molina, seeing the handwriting on the wall, met with members of the oligarchy and arranged a "compromise" that effectively weakened the program.

While the oligarchy was winning its political battles, it was also continuing to expand its economic interests. The alliance between the military and the elite enhanced industrialization, and the primacy of the coffee-growing families in the industrial sector and their alliance with foreign investment exacerbated the problems of the lower classes because it uses North American techniques, and thus is primarily capital- rather than labor-intensive. This

77 78

Montgomery, Revolution in El Salvador, p. 90. Webre, José Napoleón Duarte, pp. 193-195. 
contributes to an ever-greater concentration of wealth and confirms the fact that the traditional "developmentalist" assumption of a trickle-down effect through conventional industrialization is false.

In El Salvador the income received by the upper and middle classes tends to be spent in such a way that it remains within this upper sector or leaves the country altogether. The lower sector benefits, to a degree, from the production of local foodstuffs and from domestic service; but with the high level of incomes prevailing in much of the upper sector and the relatively small size of this group, the proportion of income spent on food is low and the market for home-produced food much smaller than it would be if incomes were distributed more equally through the population.

In this state of national economic agitation, the fifth political cycle gradually drew to a close as the 1977 election for president approached. The National Opposition Union (UNO) decided to enter the political process again after abstaining in 1976. It chose a retired colonel, Ernest claramount, to head the ticket with the former mayor of San Salvador, José Antonio Morales Erlich, as his running mate. Consistent with the past, the official party candidate, Humerto Romero, won the election which was clouded by claims of fraud and ballot box stuffing. As the UNO denounced the "stolen" election, Claramount 
and some 15,000 supporters gathered in the Plaza Libertad, where Claramount announced his readiness to "remain in the 79 plaza as long as the people want me to." Three days later the crowd had grown to 50,000, and talk of a general strike was in the air. On the night of February 27-28, the National Police moved in and attacked the crowd, killing at least four dozen people. Claramount was finally persuaded by friends to go into exile in Costa Rica, and an uneasy peace was temporarily established.

Between July 1, 1977, and October 15, 1979, El Salvador suffered increasing mass demonstrations and protests, government repression, left-wing kidnappings, labor strikes, and death squad murders. Finally, the sixth cycle began on October 15, with a golpe de estado in which a group of reform-minded junior officers ousted General Carlos Humberto Romero and set up a junta which included three civilians and three military members.

By late 1981 only two of the original members remained in the thrice reconstituted junta, by that time headed by José Napoleón Duarte. On January 3, 1980, all the civilians had resigned to protest the escalation of violence by security forces and paramilitary organizations supported by the oligarchy and integrated with sectors of the regular 
armed forces. The progressive officers could not maintain their ascendancy, and by the end of January the five progressive officers who had instigated the october 15 golpe had been driven into exile. A descent into full-scale civil war followed. 


\section{CHAPTER V}

\section{CONCLUSIONS}

It can be clearly demonstrated that the cyclical pattern of military dominance in salvadorean politics since 1931 resulted from the oligarchy's maintenance of the status quo with the masses. Economic factors constituted necessary but not sufficient motivation for maintaining a certain level of poverty and repression, however, and the history of economic growth and the evolution of social and political rights in El Salvador goes beyond a simple economic equation.

In the economic sphere, four centuries of primary production for export conditioned the terms and shape of current economic conditions in that country. This historical experience indicates that El Salvador faces a burgeoning population growth with few methods of relieving the problem. Neither industry nor agriculture is geared to the mass needs of the country.

In the political sphere, the domination of government by the power structure built and maintained by the oligarchy and the military was equally one-sided. The post-1931 period built upon and co-opted the previously existing "colonial" social structures and thereby ensured that any 
development was designed by and for the elite. For example, the rural oligarchy lost its political dominance over the military but retained its claim to agricultural dominance and to the maintenance of existing land tenure arrangements. The numerous revolutions or golpes de estado merely served to insure the economic position of the elite, with changes in political power simply changing the faces of those involved. Overall, these changes in political power contributed to the massive poverty and political repression in El Salvador. For instance, even in periods of "boom" economy the concessions to the masses failed to provide enough jobs for more than a small part of the expanding population. Similarly, entrenched rural oligarchy, a legacy of colonial era, meant the preservation of an extremely skewed distribution of income in the countryside, which remains the breeding ground for the worst kinds of Salvadorean poverty.

Even during the relatively prosperous days of CACM prior to the "Soccer War" in 1969 and in the early enthusiasm of the Alliance for Progress, the main benefactors were a privileged group within the population. Huge segments of the industrial work force as well as the rural masses were excluded from the fruits of economic progress and from the political arena.

It was just after the "Soccer War" with Honduras that 
political opposition leaders asked President Sánchez Hernández and his colleagues if, in view of their success and resultant popular support, they did not now for once have sufficient political strength to end their interdependence on the small rich oligarchy. They received no response, and the symbiotic alliance continued as strong as it was before. This most important question in Salvadorean politics, the nature of the relationship between the military and the civilian elite, remains an enigma. There is no way for an outsider to know whether the alliance is simply voluntary on the part of the officer corps, corresponding to a similarity of ideas; whether it is based simply on the wealth of the elite, with all that it implies with regard to power; or whether there are other pressures, political or otherwise, the oligarchy can bring to bear. The military in El Salvador does not appear to follow the pattern of what Frederick M. Nunn describes as professional militarism; that is, "a set of attitudes that may result in the resort to political action in an attempt to find solutions for social and economic distresses... ." while the military has evolved,

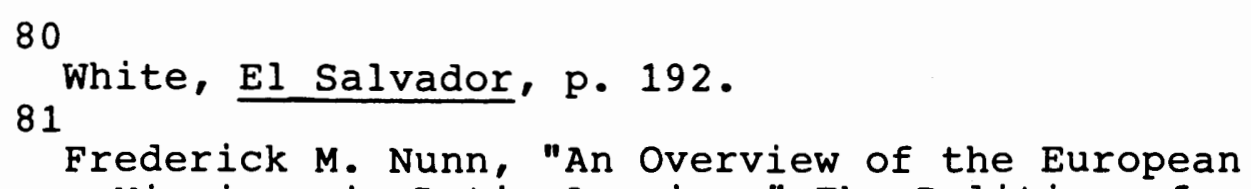
Military Missions in Latin America," The Politics of Antipolitics (Lincoln: University of Nebraska Press, 1978), p. 38 . 
through influence of European military training and orientation, into definite bodies of political interest, at least with respect to governing, it has not reached a point of true definition. The military institution in other nations of Latin America, in appearance at least, are viewed as modernizing forces of one type or another.

It is important to distinguish between political and social trade-offs in the Salvadorean development experience. Social and political aspects of their society are not identical, and in El Salvador the prospects for political freedom are progressively more bright than are those for social justice.

As I have shown, massive poverty and increasing inequality are deeply embedded in Salvadorean history. Unequal and uneven economic opportunity became entrenched during a colonial primary exporting era, and this situation has not changed in the modern period. Changing such an entrenched pattern of inequitable growth would involve a profound restructuring of the economy as well as the society.

Presuming that the current Salvadorean government truly desired to initiate a development plan that has as its goals the elimination of the worst kinds of poverty and a reduction in income inequalities, a minimum of two things would be implied: in the rural sector, a thoroughgoing land 
reform that would distribute land to landless peasants; and in the urban sector, labor-intensive industrialization to create a much more rapid rate of employment creation in the modern sector.

The current Duarte government could not foster such a program without the cooperation of the Salvadorean power elite and the army, both of whom have demonstrated over the past fifty years an overwhelming desire to maintain the status quo. Large-scale land reform has to mean the expropriation of a powerful landlord class; and to achieve this, there has to be a radical shift in the domestic balance of power. This is an excellent example of the way in which the perpetual economic self-interest of ruling groups defies attempts at true social justice.

In the sphere of industrialization policies, the Salvadorean predicament is equally stark. Domestic and multinational corporations operating in El Salvador during normal political circumstances are rational economic actors and as such would be quite willing to experiment with more labor-intensive production techniques if they had sufficient motivation to do so. But they do not, so there are severe barriers in the spheres of both production and consumption. In the sphere of political rights and civil liberties, the scope for improvements is greater. The election of José Napoleón Duarte in May 1984 brought hope for an end to civil 
conflict in El Salvador and subsequently a possibility for an era of truly democratic government. Duarte's avowed plan is to end the civil war by creating a new political environment. This would necessitate a delicate maneuvering on the part of $\mathrm{Mr}$. Duarte, requiring that he initiate policies that will ameliorate the condition of the poor and oppressed within existing institutional and political structures. Prospects for success of this approach are dismal. Middle-of-the-road reformist regimes have a mediocre track record throughout the underdeveloped world. The conservative (capitalist) and the radical (socialist) routes to the modern world constitute the starkest alternatives to the reformist or liberal efforts of the current Salvadorean regime. Both would seem to have distinct advantages, however. Conservative growth strategies offer rapid growth with at least a measure of political freedom, while socialist transformation offers a significant measure of social justice. Middle-of-the-road growth strategies run the risk of achieving neither growth nor equity.

In summation, the political cycles of the past fifty years in $E l$ Salvador featuring the rule of the military are firmly established, so firmly established in fact that in spite of the current and ambitious program of political development in El Salvador, the enmities of the past are too 
great. The vast social injustices and lawless abuses of the past half-century on the part of the military have created a gap between the left and the right in El Salvador that is too great to repair. During this period the government has obviously felt compelled to act in a bureaucratic and authoritarian manner against the popular masses so as to prevent them from becoming a power center and from putting an end to the limitations to which they are subjected. To this end, the political strategy of the government has been directed towards preventing the dominated classes from becoming masters of their own existence, a situation that has become intolerable. The ultimate result of the Salvadorean human condition has to be changed, and the possibility of violent social revolution featuring the escalation of the current leftist rebellion is at least as great as are the chances for a political democracy. 
GLOSSARY OF SPANISH TERMS

Apacero. A person who rents a plot of land for cash and/or for a portion of the harvest.

Audiencia. Court or governing body of a region; the region itself.

Cacique. Indian chief or headman; local boss.

Campesino. Peasant or agricultural worker or poor rural person.

Campo padado. A paid political advertisement; includes mainfestos, ads, commentaries, etc.

Colono. A person who works on an hacienda in exchange for shelter and a small plot of land on which to grow subsistence crops.

Criollo. Spanish person born in the colonies.

Encomendero. Holder of an encomienda.

Encomienda. Right to receive tribute from Indians of a certain village.

Finca. A cash-crop farm of less than 100 hectares; a coffee plantation of any size.

Golpe de estado, or golpe. Coup d'etat; the sudden overthrow of a government, usually by one faction within the army.

Hacendado, hacendero. Owner of a hacienda.

Hacienda. Estate of over 100 hectares, not under ocffee.

Hectare. 2.47 acres.

Mestizo. A person of mixed white and Indian ancestry.

Milpa. A small plot of land, usually one hectare or less, which a peasant is given or rents from a patron on which to grow subsistence crops such as maize. 
Patrón. The owner of a farm or hacienda; the boss.

Repartimiento. A system of draft labor on a rotating quota basis. Also forced purchases or sales of crops and other goods imposed on Indians or peasants. 


\section{A SELECTED BIBLIOGRAPHY}

This bibliography consists of the works consulted in writing this thesis. It includes the most salient sources in English, with selected works in translation of the original Spanish. Conversations with citizens of El Salvador and research done in that country are not noted because notes referring to those resources have been destroyed. In deciding what was credible and whom to believe I have tried to apply a few relatively simple tests. of most importance seems to me the logic of events, the reading which best explains the really potent happenings, such as the Matanza, the various golpes de estado, or laws passed to benefit a particular group of society.

\section{SALVADOREAN HISTORY}

Anderson, Thomas P. Matanza, El Salvador's Communist Revolt of 1932. Lincoln: University of Nebraska Press, 1971.

This is an excellent reference to the events leading up to the Matanza and government reaction both during and after the event.

The War of the Dispossessed: Honduras and El Salvador, 1969. Lincoln: University of Nebraska Press, 1981. 
Blutstein, Howard I. and others. Area Handbook for El

Salvador. Washington, D.C.: U.S. Government Printing Office, 1971.

The handbook contains much useful material presented in a precise manner; unfortunately, it avoids controversy.

Browning, David. El Salvador: Landscape and Society.

Oxford: Clarendon Press, 1971.

Originally written as a doctoral thesis in historical geography, much of the general history of El Salvador is accessible in this work.

White, Alastair. El Salvador. New York: Praeger Publishers, 1973.

This is the definitive, all-round history of El

Salvador. Much of my understanding of the economic, political, and social problems of the country were defined in this work.

\section{THE MILITARY IN LATIN AMERICA}

Bienen, Henry, ed. The Military and Modernization. Chicago: Aldine-Atherton, 1971.

This collection of essays by social scientists who researched the role of the military in post-World war II politics gave me much insight into the subject.

Elam, Robert Varnen. "Appeal to Arms: Army and Politics in El Salvador 1931-1964," Ph.D. dissertation, University of New Mexico, 1968.

Janowitz, Morris. The Military in the Development of New Nations. Chicago: The University of Chicago Press, 1971.

The author offers insight into the military-oligarchy relationship as well as alternative coalitions. 
Johnson, John J. Political Change in Latin America. Palo Alto: Stanford University Press, 1958 .

Johnson's perception of the continuing relationship between the elite and the other institutions which did not hesitate to use force in place of reason: the Church and the military, aided me greatly in my attempt to analyze El Salvador's political dilemma.

Lieuwen, Edwin. Generals vs. Presidents: Neo-militarism in Latin America. New York: Frederick A. Praeger, 1964 .

U.S. Policy in Latin America. New York: Frederick A. Praeger, 1965.

Both works are beneficial in understanding Latin American political behavior. Generals vs. Presidents generally views the military as a force that prevents reform and change, maintaining the status quo.

Nunn, Frederick M. "An Overview of the European Military Missions in Latin America." The Politics of Antipolitics. Lincoln: University of Nebraska Press, 1978.

Dr. Nunn provides insight into the evolution of the military mentality of contemporary Latin America.

III. RECENT (1981-1984) WORKS CONCERNING EL SALVADOR

To annotate each work listed would be cumbersome.

They range from liberal to radical in their

interpretation of Salvadorean political events

both before and after the change of government on

October 15, 1979. In using these as research

resources, I have exercised extreme care in

determining the logic of events.

Armstrong, Robert and Phillip wheaton. Reform and

Repression: U.S. Policy in El Salvador. San

Francisco: Solidarity Publications, 1983.

An analytical monograph describing "Reagan's War" in El Salvador, 1981-1983. 
Barry, Tom and others. Dollars and Dictators. New York: Grove Press, 1983.

Describes U.S. and multinational corporate interests in Central America.

Chace, James. Endless War. New York: Vintage Books, 1984. A radical political editorial.

Gettleman, Marvin E. and others. El Salvador: Central America in the Cold War. New York: Grove Press, 1981.

A collection of critical essays, etc., regarding the "hawkish" stance of the U.S. in Central America.

Montgomery, Tommie Sue. Revolution in El Salvador. Boulder: Westview press, 1982.

A well-researched, though politically biased, history of the current revolution in El Salvador. The six political cycles on which I based my thesis were abstracted from this work.

North, Lisa. Bitter Grounds: Roots of Revolt in El Salvador. Toronto: Between the Lines, 1981.

A Canadian political scientist's analysis of the Salvadorean revolt.

Pearce, Jenny. Under the Eagle. London: South End Press, 1981 .

A critical analysis of U.S. dominance in Central America by a British author.

Among other works researched under the above category were:

Hadar, Arnon. The United States and El Salvador: Political and Military Involvement. Berkeley: U.S.-El Salvador Research and Information Center, 1981.

Kunnes, Rick, ed. El Salvador: No Middle Ground. Chicago: New American Movement, 1981. 
Rodrĺguez, Mario Menéndez. Voices From El Salvador (from the original Spanish edition, El Salvador: Uta Auténtica Guerra Civil). San Francisco: Solidarity Publications, 1965.

IV. GENERAL WORKS CONSULTED, LATIN AMERICAN AUTHORS

Aguilar, Alonso. Pan-Americanism From Monroe to Present. New York: Monthly Review Press, 1968.

Furtado, Celso. Obstacles to Development in Latin America. New York: Doubleday \& Company, 1970.

Picón-Salas, Mariano. A Cultural History of Spanish America. Berkeley: University of California Press, 1968.

Piedra, Alberto Martínez, ed. Socio-Economic Change in Latin America. Washington, D.C.: The Catholic University Press, 1970.

V. GENERAL WORKS CONSULTED, NORTH AMERICAN AUTHORS

Alexander, Robert J. Communism in Latin America. New Brunswick: Rutgers University Press, 1957.

Atkins, G. Pope. Latin America in the International Political system. New York: The Free Press, 1977.

Cockcroft, James D. and others. Dependence and Underdevelopment. New York: Doubleday \& Company, 1972 .

Douglas, William 0 . Holocaust or Hemispheric Co-op: Cross Currents in Latin America. New York: Vintage Books, 1971.

Flemion, Philip F. Historical Dictionary of El Salvador. Metuchen, N.J.: The Scarecrow Press, 1972.

Gardiner, Patrick, ed. Theories of History. New York: The Free Press, 1959. 
Gibson, Charles. Spain in America. New York: Harper \& Row, 1966.

Gil, Federico C. Latin American-United States Relations. New York: Harcourt Brace Jovanovich, 1971.

Glauert, Earl T. and Lester D. Langley, eds. The United States and Latin America. Reading, Mass.: AddisonWesley Publishing, 1971.

Haverstock, Nathan A. and John P. Hoover. El Salvador. New York: Sterling Publishing Co., 1976.

Hewlett, Sylvia Ann. The Cruel Dilemmas of Development. New York: Basic Books, Inc., 1980.

Loveman, Brian and Thomas M. Davies, Jr., eds. The Politics of Antipolitics. Lincoln: the University of Nebraska Press, 1978.

MacLeod, Murdo J. Spanish Central America: A Socioeconomic History 1520-1720. Berkeley: University of California Press, 1973.

Parkinson, F. Latin America, The Cold War, \& the World Powers 1945-1973. Beverly Hills: Sage Publications, 1974.

Rodríguez, Mario. Central America. Englewood Cliffs, N.J.: Prentice-Hall, 1965 .

Schurz, William Lystle. Latin America. New York: E. P. Hutton \& Co., 1964.

Tambs, Lewis A., ed. United States Policy Toward Latin America. Tempe: Arizona State University Center for Latin American Studies, 1975.

Webre, Stephen. José Napoleón Duarte and the Christian Democratic party in Salvadoran Politics 1960-1972. Baton Rouge: Louisiana State University Press, 1979.

West, Robert C. and John F. Augelli. Middle America Its Lands and Peoples. Englewood Cliffs: Prentice-Hall, 1976.

Wiarda, Howard J., ed. Politics \& Social Change in Latin America. Amherst: University of Massachusetts Press, 1974 . 
Wilkie, James $w$. Statistics and National Policy. Los Angeles: University of California Media Production, 1974 .

Williams, Edward J. Latin American Political Thought: A Developmental Perspective. Tuscon: The University of Arizona Press, 1974.

\section{A SELECTION OF PERIODICAL REFERENCES}

It is obvious that periodical references to El Salvador in recent times would be too numerous to list, although they are certainly pertinent to the thesis topic. I have selected several articles written shortly after the revolution.

Burbach, Roger. "Rereading Haig's Secret Document." Mother Jones, June 1981.

Chávez, Lydia. "The Testing of Jose Napoleon Duarte." The New York Times Magazine, September 2, 1984.

DeYoung, Karen. "White Hand of Terror." Mother Jones, June 1981.

Dowie, Mark. "Behind the Myth of Land Reform." Mother Jones, June 2981.

Emediato, Luiz Fernando. "the Suffering Refugees." 10. Estado de s. Paulo), World Press Review, April 1981.

Gerrasi, John. "America's Hit List." Mother Jones, June 1981 .

Migdail, Carl. "El Salvador: Will It Turn Into Another Vietnam?" U.S. News \& World Report, March 16, 1981.

Naumann, Michael. "Anatomy of a Revolution." (Hamburn Die Ziet), world Press Review, April 1981.

O'Shaughnessy, Hugh and David Buchan. "A President's First Test." (London Financial Times), World Press Review, April 1981.

Spake, Amanda. "Time to Talk Back to Your TV Set." Mother Jones, June 1981. 
Von Conta, Manfred. "One Hundred Years of Horror."

(Hamburg newsmagazine STERN), World Press Review, April 1981. 